\title{
Diagnosis Dini Tuberkulosis pada Kontak Serumah dengan Penderita Tuberkulosis Paru melalui Deteksi Kadar IFN- $\gamma$
}

\author{
Early Diagnosis of Tuberculosis Infection for Household Contact with \\ Patients of Pulmonary Tuberculosis Use Interferon (IFN- $\gamma$ ) Level Detection
}

Sri Andarini Indreswari, Suharyo

Program Studi Kesehatan Masyarakat Fakultas Kesehatan Universitas Dian Nuswantoro Semarang

\begin{abstract}
Abstrak
Tuberkulosis paru masih merupakan masalah dunia. Indonesia menempati peringkat ke tiga di dunia pada tahun 2012. Target nasional Case Detection Rate tahun 2012 adalah 70\%, sedangkan pencapaian Jawa Tengah sebesar $58,48 \%$. Penelitian ini bertujuan untuk memperoleh batas kadar interferon (IFN) $\gamma$ pada orang kontak serumah dengan penderita tuberkulosis paru sebagai dasar diagnosis dini penyakit tuberkulosis. Penelitian dilakukan secara kohort selama dua tahun (2011 - 2013) di Balai Kesehatan Masyarakat Paru Semarang. Pada akhir penelitian, terdapat 12 responden kontak dan 13 tidak kontak serumah. Uji Wilcoxon menunjukkan perbedaan bermakna rerata kadar IFN- $\gamma$ antara kelompok kontak dengan kelompok tidak kontak serumah ( nilai $p=0,004$ ). Rerata kadar IFN- $\gamma$ pada kontak serumah mengalami penurunan pada sebagian besar kasus $(75 \%)$. Pada kelompok kontak serumah, 25\% menunjukkan gejala klinis suspek tuberkulosis paru. Pemeriksaan mikrobiologis menunjukkan $100 \%$ negatif pada kedua kelompok. Hasil reciever operating characteristic kadar IFN- $\gamma$ terhadap status klinis, diperoleh nilai area under the curve sebesar 70,4\% $(95 \% \mathrm{Cl}=40,8 \%$ - 99,9\%). Nilai cut off point IFN- $\gamma$ yang optimal secara statistik yaitu pada nilai $\geq 3,277$. Diperoleh hasil sensitivitas dan spesifisitas sebesar $67,7 \%$. Pemeriksaan kadar IFN- $\gamma$ dapat digunakan dalam kegiatan skrining untuk mendeteksi secara dini penularan pada kontak serumah dengan penderita tuberkulosis paru, sebagai pilot project pada daerah dengan prevalensi tuberkulosis paru yang tinggi.

Kata kunci: Kadar IFN- $\gamma$, kontak serumah, tuberkulosis paru
\end{abstract}

\section{Abstract}

Tuberculosis remains a global problem. In 2012, Indonesia has the third biggest tuberculosis cases in the world. The national target in Case Detection Rate for tuberculosis in 2012 was $70 \%$, whereas Jawa Tengah reached only $58.48 \%$. This research aimed to find interferon (IFN) $\gamma$ level among households contact with tuberculosis patient that used a new screening method of finding tuberculosis cases. The research design was a two-year cohort study (2011 - 2013) took place in pulmonary community health centers Semarang. In the end of research, found 12 participants household contact and 13 participants nonhousehold contact. Wilcoxon test result showed significant differences IFN- $\gamma$ level between contact group and noncontact group ( $p$ value $=0.004$ ). IFN- $\gamma$ among household contact group decreased in most cases (75\%). Among household contact group showed $25 \%$ had a clinical symptom of tuberculosis. Microbiology diagnostic showed $100 \%$ had negative result in both group. Result of receiver operating characteristic IFN- $\gamma$ level toward clinical status, had value area under curve $70.4 \%$ (95\% Cl= 40.8\%-99.9\%). Cut off point of IFN- $\gamma$ value have optimal result in $\geq 3.277$, with sensitivity and specificity value $67.7 \%$. IFN- $\gamma$ level test can be used in screening program to early detection of infected among household contact with new tuberculosis cases, as a pilot project in high prevalence of new tuberculosis cases.

Keywords: IFN- $\gamma$ level, household contact, tuberculosis

\section{Pendahuluan}

Strategi penemuan pasien tuberkulosis baru tidak hanya melalui penemuan secara pasif, tetapi penemuan secara aktif juga sangat diperlukan. ${ }^{1}$ Seseorang dapat tertular tuberkulosis selain ditentukan oleh konsentrasi kuman yang terhirup, lama kuman terhirup, virulensi kuman, umur juga dipengaruhi oleh keadaan gen dari orang tersebut. Tidak semua kuman yang masuk ke dalam tubuh dapat menyebabkan sakit, hal ini tergantung dari kerentanan tubuh sebagai akibat interaksi beberapa faktor di dalam tubuh misalnya status gizi, imunisasi, kepadatan hunian dan gen individu tersebut. ${ }^{2}$

Korespondensi: Sri Andarini Indreswari, Program Studi Kesehatan Masyarakat Fakultas Kesehatan UDINUS, Jl. Nakula I No. 5-11 Semarang, Hp. 0818292788,e-mail: andarini@dosen.dinus.ac.id 
Sesuai laporan World Health Organization (WHO), kejadian tuberkulosis tertinggi adalah di Asia dan Afrika. India dan China merupakan penyumbang terbesar kasus tuberkulosis di dunia yaitu sebesar 40\%. Sebesar 60\% kasus tuberkulosis tersebar di Asia Tenggara, dan daerah Barat Pasifik. Afrika merupakan benua yang menyumbangkan 24\% kasus tuberkulosis di dunia, serta mempunyai kasus kematian perkapita tertinggi di dunia. Menurut laporan WHO tahun 2013, Indonesia menduduki peringkat ketiga di dunia setelah India dan Cina dalam hal jumlah prevalensi kasus tuberkulosis secara keseluruhan. ${ }^{3}$ Apabila melihat target yang ditetapkan pada Millenium Development Goals (MDGs) bahwa pada tahun 2015 ditetapkan angka kematian yang disebabkan oleh tuberkulosis menurun 50\% sejak tahun 1990, pada tahun 2011 sudah tercapai penurunan sebesar $41 \%$ di seluruh dunia. ${ }^{4}$

Annual Risk of Tuberculosis Infection (ARTI) di Indonesia berkisar antara 1-3\% , berarti 10 - 30 (sepuluh sampai tiga puluh) orang di antara 1000 penduduk berisiko terinfeksi tuberkulosis setiap tahun. Hal ini menunjukkan bahwa tuberkulosis masih merupakan masalah besar di Indonesia. ${ }^{2}$ Proporsi pasien tuberkulosis dengan basil tahan asam positif (BTA+) di antara suspek yang diperiksa pada tahun 2009 masih di dalam rentang target yang diharapkan (5-15\%), sedangkan pada tahun 2010 triwulan 1 besar proporsi adalah $11 \%$. Angka ini dapat diartikan bahwa apabila sebesar $\leq 15 \%$ penjaringan suspek terlalu longgar, tidak memenuhi kriteria suspek atau terdapat masalah di dalam pemeriksaan laboratorium (terdapat negatif palsu). Sebaliknya, apabila proporsi adalah $>15 \%$, dapat diartikan kemungkinan terdapat penjaringan terlalu ketat, atau terdapat masalah di dalam pemeriksaan laboratorium (terdapat positif palsu). ${ }^{2}$ Angka penjaringan suspek di Provinsi Jawa Tengah tidak mengalami kenaikan, pada tahun 2009 sebesar 186 dan pada tahun 2010 sebesar 144. Angka notifikasi kasus di Jawa Tengah mengalami peningkatan, pada tahun 2009 sebesar 36 untuk keseluruhan kasus, 14 untuk kasus BTA+, sedangkan tahun 2010 sebesar 13 untuk keseluruhan kasus dan 37 untuk kasus BTA+. ${ }^{5}$ Prevalensi tuberkulosis di Jawa Tengah tahun 2012 sebesar 60,87\%, sedangkan angka kesembuhan tahun 2012 sebesar 82,90\% masih di bawah target nasional sebesar $85 \%$, mengalami penurunan dibanding tahun 2011 sebesar 85,15\%. Target nasional Case Detection Rate (CDR) untuk penemuan pasien baru tuberkulosis dengan BTA+ tahun 2012 adalah $70 \%$, sedangkan Jawa Tengah tahun 2010 mencapai 55,38\%. Tahun 2011 sebesar 59,52\%, sedangkan tahun 2012 sebesar 58,48\%. Kota Semarang tahun 2012 sebesar 68,1\%, sedangkan Kabupaten Semarang sebesar 26,2\% (nomor 2 terendah di Provinsi Jawa Tengah). ${ }^{6}$
Apabila melihat data-data tersebut, kita optimis bahwa penanggulangan tuberkulosis di dunia, Indonesia, serta khususnya di Jawa Tengah perkembangannya sudah cukup baik, akan tetapi belum optimal karena diperkirakan masih banyak kasus tuberkulosis yang belum ditemukan. ${ }^{6}$ Penetapan suatu kebijakan baru di dalam penemuan kasus tuberkulosis di masyarakat dipandang perlu dilakukan. Hasil penelitian tahun 2011 pada awal terjadi pajanan tentang kadar interferon- $\gamma($ IFN- $\gamma$ ) pada kontak serumah dengan penderita tuberkulosis, menggambarkan bahwa terdapat perbedaan bermakna rata-rata kadar IFN- $\gamma$ antara kelompok terpajan dengan kelompok tidak terpajan kontak serumah dengan penderita tuberkulosis. Proporsi subjek dengan kadar IFN- $\gamma \geq 15,7 \mathrm{pg} / \mathrm{mL}$ pada kelompok terpajan $(5,9 \%)$ lebih besar dibandingkan kelompok tidak terpajan $(0,0 \%) \cdot{ }^{3}$ Meskipun telah banyak penelitian menyebutkan bahwa Quanti Feron-TB Gold (QFT-G), T-SPOT TB assays, dan interferon- $\gamma$ release assay (IGRA) dapat digunakan sebagai alat diagnostik untuk tuberkulosis aktif atau laten dengan spesifitas dan sensitivitas yang telah diteliti. 7,8

Centers of Disease Control and Prevention (CDC) telah membuktikan human IFN- $\gamma$ kit mempunyai sensitivitas dan spesifisitas yang tinggi. ${ }^{9}$ Mengingat harga $h u-$ man IFN- $\gamma$ kit tersebut jauh lebih mahal, maka penelitian ini masih menggunakan kit IFN- $\gamma$ yang belum ditambahkan antigen tuberkulosis atau bakteri Mycobacterium tuberculosis yang dilemahkan. Di luar negeri pun terdapat penelitian yang masih menggunakan kit yang sama.

Penelitian ini bertujuan menganalisis perbedaan IFN$\gamma$ pada kelompok kontak serumah dengan penderita tuberkulosis (individu terpajan) dan tidak kontak serumah (individu tidak terpajan) dan menghitung cut off point kadar IFN- $\gamma$ setelah diikuti selama 2 tahun. Selain itu, penelitian ini juga mendeskripsikan perkembangan individu terpajan maupun tidak terpajan secara klinis dan bakteriologis (pemeriksaan BTA dari dahak).

\section{Metode}

Penelitian dilakukan di Balai Kesehatan Masyrakat Paru (BKPM) Semarang dengan mengikuti individu kontak serumah (dengan penderita tuberkulosis paru BTA + yang mendapatkan pengobatan strategi Directly Observed Treatment Shortcourse (DOTS)) sejumlah 34 orang (ditetapkan sebagai kelompok terpajan) dan tidak kontak serumah sejumlah 34 orang (ditetapkan sebagai kelompok tidak terpajan) selama tahun 2011-2013. Terdapat kejadian drop-out sehingga penelitian pada tahun 2013 hanya mendapatkan 12 orang kontak dan 13 orang tidak kontak serumah.

Rancangan penelitian adalah diagnostik dengan pendekatan kohort selama 2 tahun. Penelitian ini merupakan penelitian lanjutan, kelompok terpajan dan tidak terpajan 
diperiksa keadaan klinis oleh dokter bagian penyakit tuberkulosis di BKPM Semarang, diperiksa dahak di Laboratorium BKPM, diambil darah 3 cc di BKPM, kemudian diukur kadar IFN- $\gamma$ di Laboratorium Gizi Fakultas Kedokteran Univeristas Diponegoro, penetapan cut off point dari IFN- $\gamma$ dengan perhitungan receiver operating characterictic (ROC). Penelitian pertama meliputi tahap identifikasi kasus yang tinggal serumah minimal 6 bulan dengan penderita dan dilakukan pemeriksaan Mantoux, sedangkan kontrol tidak tinggal serumah dengan penderita tuberkulosis paru. Tahap kedua dilakukan pemeriksaan klinis dan kadar IFN- $\gamma$. Analisis data menggunakan tes Wilcoxon untuk menguji hipotesis komparatif dan ROC untuk menganalisis kekuatan uji diagnostik. Statistik optimum antara sensitifitas dan spesifisitas digunakan untuk mencari cut of point dari kadar IFN- $\gamma$ pada orang kontak serumah dengan penderita tuberkulosis paru.

Pemeriksaan kadar IFN- $\gamma$ dilakukan dengan menggunakan Quantikine Human IFN-Immunoassay Cat. No. DIF50, 96 tests. Darah dimasukkan dalam vacutainer disentrifuge selama 10 menit pada $3000 \mathrm{rpm}$. Kemudian serum dipisahkan sebanyak $1 \mathrm{cc}$, disimpan di dalam freezer dengan suhu $-80^{\circ} \mathrm{C}$. Selanjutnya, disiapkan reagen pada Quantikine Human IFN-Immunoassay Cat. No. DIF50, 96 tests. Pengujian dilakukan pada suhu ruang dengan beberapa langkah. Langkah pertama menyiapkan semua reagen dan standar sesuai yang ditentukan, kemudian menambahkan 100 uL Assay Diluent RD1-51 pada setiap well 1 dan $100 \mathrm{uL}$ standar, kemudian masukkan sampel atau kontrol ke setiap well selama 15 menit dan diinkubasi 2 jam. Setelah diinkubasi, dilakukan aspirasi dan dicuci 4 kali. Conjugate sebanyak $200 \mathrm{uL}$ ditambah ke dalam masing-masing well lalu diinkubasi 2 jam. Kemudian diaspirasi dan dicuci 4 kali. Tambahkan $200 \mathrm{uL}$ substrate solution ke setiap well kemudian diinkubasi selama 30 menit dan terhindar dari cahaya. Lalu, tambahkan $50 \mathrm{uL}$ stop solution ke setiap well. Baca pada $450 \mathrm{~nm}$ selama 30 menit correction 540 atau $570 \mathrm{~nm} .{ }^{10}$

Pemeriksaan klinis dilakukan oleh dokter di BKPM Kota Semarang. Hal tersebut dilakukan untuk menentukan dampak pajanan dari kontak serumah selama dua tahun. Hasil ditetapkan apakah penderita termasuk kategori suspek tuberkulosis atau tidak suspek tuberkulosis. Gejala klinis tuberkulosis dibagi menjadi dua golongan, yaitu gejala lokal dan gejala sistemik. Gejala lokal pada tuberkulosis paru adalah gejala respiratorik, meliputi batuk lebih dari dua minggu, batuk darah, sesak napas, serta nyeri dada. Gejala dapat sangat bervariasi, mulai dari tidak terdapatnya gejala sampai gejala yang sangat berat, tergantung dari luasnya lesi pada paru. Gejala sistemik pada tuberkulosis paru meliputi demam, malaise, berkeringat pada malam hari, anoreksia, dan berat badan turun. Disebut suspek status klinis positif, bila terdapat minimal sebagian gejala sistemik, serta minimal terdapat sebagian gejala lokal yaitu batuk produktif lebih dari dua minggu dengan atau tanpa batuk darah, sesak napas serta nyeri dada.

Pemeriksaan bakteriologi dilakukan secara mikroskopis dengan pewarnaan Ziehl-Nielsen pada semua responden pada kelompok terpajan dan tidak terpajan. Interpretasi hasil pemeriksaan dahak dari tiga kali pemeriksaan. BTA positif jika 3 kali positif atau 2 kali positif 1 kali BTA negatif. Jika 1 kali positif 2 kali negatif, ulang BTA 3 kali. Kemudian bila 1 kali positif 2 kali negatif, berarti BTA positif. Bila tiga kali negatif, hasilnya BTA negatif. ${ }^{2}$

Cara pengambilan dahak SPS, meliputi S (sewak$\mathrm{tu}$ )/spot, dahak sewaktu saat kunjungan P (pagi), keesokan harinya. S (sewaktu)/spot, pada saat mengantarkan dahak pagi. Bahan/spesimen/dahak yang berbentuk cair/kental, dimasukkan ke dalam pot bermulut lebar, berpenampang $6 \mathrm{~cm}$ atau lebih. Pot berulir, dari bahan yang tidak mudah pecah dan tidak bocor. Pot berisi dahak diperiksa di laboratorium BKPM, sudah diberi label. Apabila pot dikirim, telah dipastikan tidak tumpah, diberi label, kemudian ditempatkan pada wadah. Reagen Ziehl Neelsen merupakan reagen terdiri dari karbol fuchsin 0,3\%, asam alkohol 3\%, dan methylen blue $0,3 \% .^{2}$

Hasil pemeriksaan Elisa dengan Human Interferon Kit yang dilakukan oleh tenaga analis di Laboratorium Gizi Fakultas Kedokteran Universitas Diponegoro untuk IFN- $\gamma$ antara kelompok terpajan dan tidak terpajan akan diperbandingkan, kemudian dianalisis dengan ROC, untuk menetapkan cut off point. Hasil pemeriksaan klinis bagi kelompok terpajan dan tidak terpajan dianalisis untuk melihat perkembangan klinisnya.

\section{Hasil}

Semua pemeriksaan BTA (SPS) menunjukkan hasil yang negatif, baik pada kelompok orang yang kontak serumah dengan penderita tuberkulosis paru maupun tidak kontak serumah. Kondisi sebagian responden yang sehat (tidak mengalami gejala batuk) menyebabkan kesulitan dalam pengambilan dahak yang berkualitas untuk pemeriksaan BTA. Sedangkan hasil pemeriksaan klinis ditunjukkan pada Tabel 1.

Tabel 1. Distribusi Status Klinis Responden Berdasarkan Riwayat Kontak Serumah dengan Penderita Tuberkulosis Paru

\begin{tabular}{|c|c|c|c|c|c|c|}
\hline \multirow{3}{*}{ Riwayat Kontak Serumah } & \multicolumn{4}{|c|}{ Status Klinis } & \multirow{2}{*}{\multicolumn{2}{|c|}{ Total }} \\
\hline & \multicolumn{2}{|c|}{ Positif } & \multicolumn{2}{|c|}{ Negatif } & & \\
\hline & f & $\%$ & f & $\%$ & $\mathbf{F}$ & $\%$ \\
\hline Kontak serumah & 3 & 25,0 & 9 & 75,0 & 12 & 100,0 \\
\hline Tidak kontak serumah & 0 & 0,0 & 13 & 100,0 & 13 & 100,0 \\
\hline
\end{tabular}


Setelah diikuti selama dua tahun, kelompok yang kontak serumah dengan penderita tuberkulosis paru, terdapat 25\% yang menunjukkan gejala klinis seperti batuk, nafsu makan berkurang, dan berkeringat dingin di malam hari (Tabel 1). Gejala ini menunjukkan adanya suspek tuberkulosis. Sedangkan pada kelompok yang tidak kontak serumah dengan penderita tuberkulosis paru, setelah diikuti selama dua tahun, semuanya tidak menunjukkan gejala klinis.

Hasil pemeriksaan kadar IFN- $\gamma$ pada Gambar 1 menunjukkan baik pada kelompok yang kontak serumah maupun tidak kontak serumah dengan penderita tuberkulosis paru kadarnya di bawah $15,7 \mathrm{pg} / \mathrm{mL}$. Rerata kadar IFN- $\gamma$ pada kontak serumah dengan penderita tuberkulosis paru lebih besar (hampir empat kali lipat) dibandingkan dengan kelompok yang tidak kontak serumah. Sedangkan nilai maksimal kadar IFN- $\gamma$ pada kontak serumah hampir tujuh kali lipat lebih besar dibanding pada kelompok yang tidak terpapar. Setelah dua tahun berlangsung pajanan, kadar IFN- $-\gamma$ berbeda secara signifikan (nilai $\mathrm{p}=0,004$ ) antara kelompok kontak serumah dengan yang tidak kontak serumah dengan penderita tuberkulosis paru (Gambar 1).

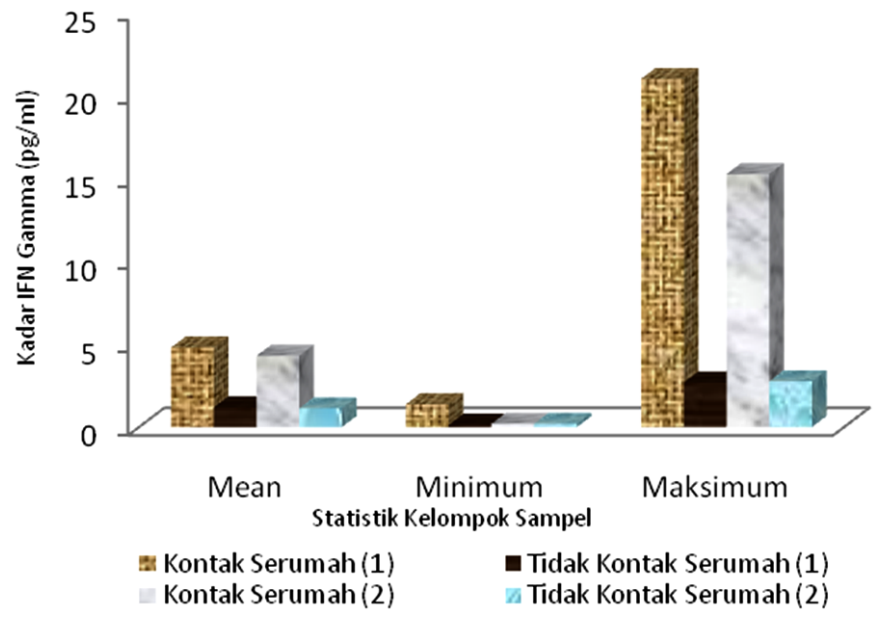

Gambar 1. Perbandingan IFN- $\gamma$ antar Kelompok Sampel pada Tahun 2011 (1) dengan Tahun 2013 (2)

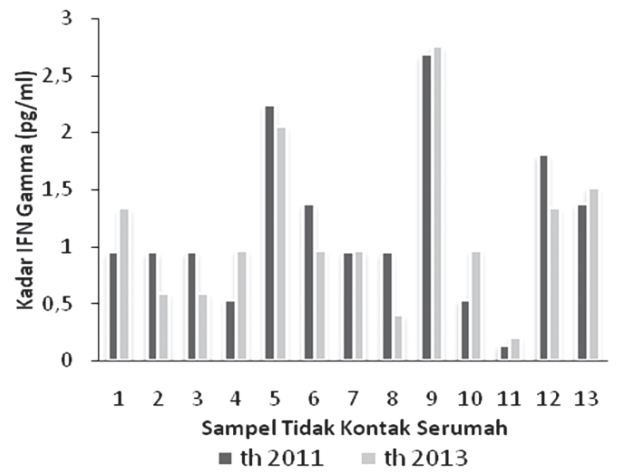

Jika dibandingkan dengan pemeriksaan kadar IFN- $-\gamma$ dua tahun yang lalu, reratanya baik pada kontak serumah maupun tidak kontak serumah mengalami penurunan berkisar $12,5 \%$. Demikian pula pada nilai minimum maupun maksimum, mengalami penurunan hampir sepertiganya. Namun pada kelompok yang tidak kontak serumah sedikit mengalami kenaikan berkisar $0,1 \mathrm{pg} / \mathrm{mL}$ baik pada nilai minimum maupun maksimum.

Perbandingan kadar IFN- $\gamma$ pada kelompok sampel tidak kontak serumah antara awal pengamatan (tahun 2011) dan setelah diikuti selama dua tahun (tahun 2013) dapat dilihat pada Gambar 2. Hasil perbandingan kadar IFN- $\gamma$ pada kelompok kontak serumah dengan penderita tuberkulosis paru setelah dua tahun diikuti, sebagian besar $(75 \%)$ mengalami penurunan. Demikian pula pada kelompok yang tidak kontak serumah, 65\% mengalami penurunan pada kadar IFN- - .

Gambar 3 menunjukkan bahwa kadar IFN- $\gamma$ mempunyai nilai diagnostik yang cukup baik karena kurva jauh dari daris 50\% dan mendekati 100\%. Hasil analisis diperoleh area under curve (AUC) sebesar 70,4\% $(95 \% \mathrm{CI}=40,8 \%-99,9 \%)$. Secara statistik, nilai 70,4\% tergolong cukup kuat untuk mendiagnosis tuberkulosis. Ini berarti jika kadar IFN- $\gamma$ digunakan untuk mendiagnosis tuberkulosis pada 100 orang yang kontak serumah dengan penderita tuberkulosis paru. Kesimpulan hasil pemeriksaan yang tepat akan diperoleh 70 orang yang suspek tuberkulosis. Namun demikan, hasil penelitian menunjukkan nilai $\mathrm{p}$ 0,309. Artinya AUC yang diperoleh belum berbeda secara bermakna dengan nilai AUC $50 \%$. Secara klinis, nilai AUC kadar IFN- $\gamma$ sudah memuaskan karena lebih besar dari yang diharapkan yaitu $70 \%$.

Guna keperluan skrining, hasil analisis menunjukkan bahwa cut off point kadar IFN- $\gamma$ pada kontak serumah dengan penderita tuberkulosis paru, diambil nilai dengan sensitifitas dan spesifitas yang optimal secara statistik, yaitu pada nilai 3,277 dengan nilai sensitifItas dan spesi-

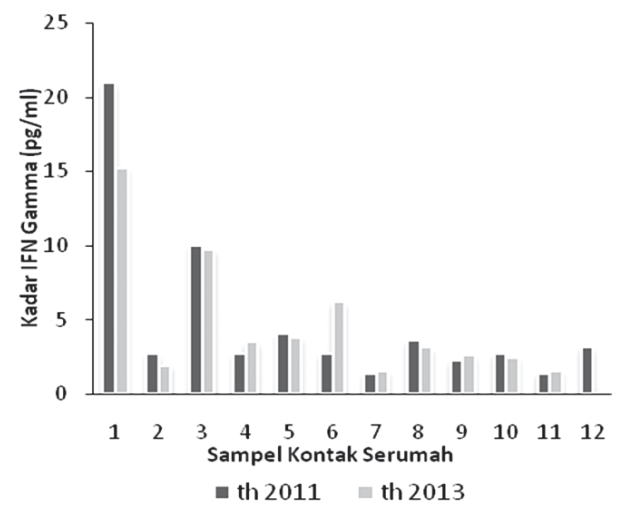

Gambar 2. Perbandingan Kadar IFN- $\gamma$ pada kelompok Kontak dan Tidak Kontak Serumah dengan Penderita Tb paru antara tahun 2011 dengan 2013 di Kota Semarang 


\section{ROC Curve}

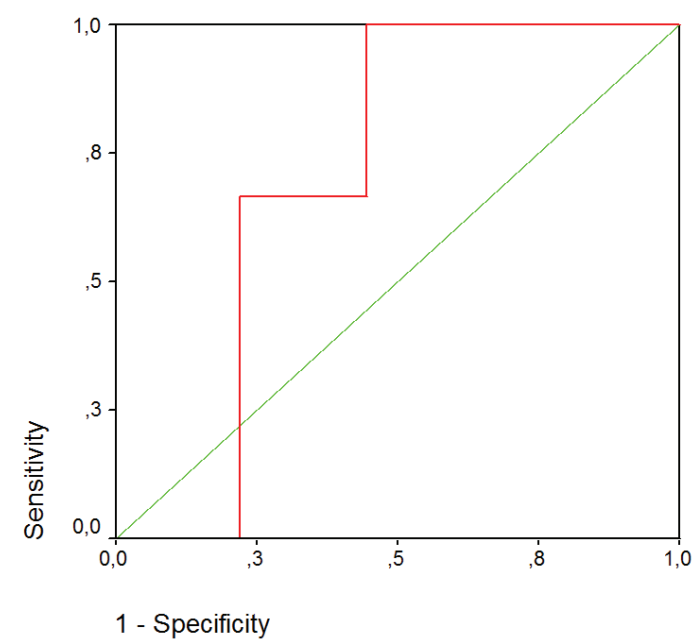

Gambar 3. Kurva ROC Kadar IFN- $\gamma$ terhadap Status Klinis pada Kelompok yang Kontak Serumah dengan Penderita Tuberkulosis Paru

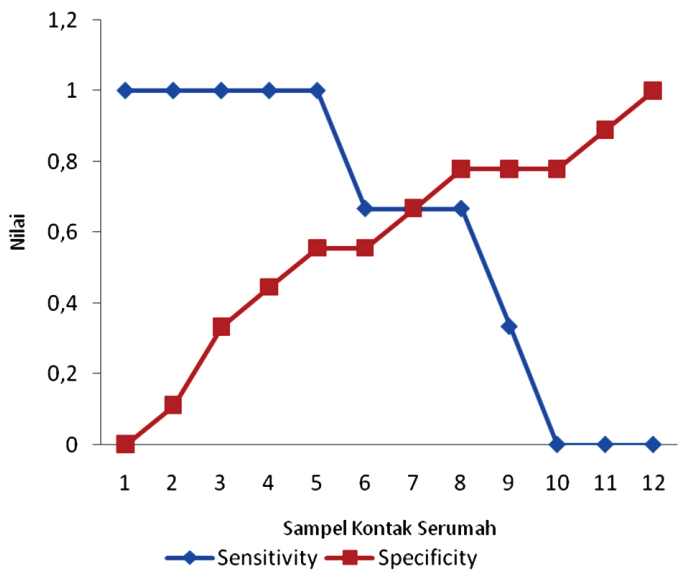

Gambar 4. Kurva ROC Kadar IFN- $\gamma$ terhadap Status Klinis pada Kelompok yang Kontak Serumah dengan Penderita Tuberkulosis
Paru

fitas masing-masing sebesar 67,7\% (Gambar 4).

\section{Pembahasan}

Riwayat kontak serumah dengan penderita tuberkulosis paru memberikan kontribusi terhadap perkembangan tuberkulosis dalam tubuh orang yang sehat. Hasil penelitian menunjukkan bahwa kadar interferon sebagian besar mengalami penurunan selama dua tahun. Hal ini seiring dengan sumber kontak yang telah mendapatkan pengobatan dan rerata kadar IFN- $\gamma$ pada sumber kotak serumah sebesar 3,48 pg/mL. Kadar tersebut juga lebih rendah dari rerata IFN- $\gamma$ pada saat sakit yaitu 23,70 $\mathrm{pg} / \mathrm{mL} .{ }^{11} \mathrm{Hal}$ ini juga selaras dengan hasil penelitian yang menyebutkan bahwa kontribusi riwayat kontak memberikan kontribusi terhadap hasil tes tuberkulin positif sebesar $90,7 \% .^{12}$

Negara-negara maju di dunia pada umumnya telah melakukan metode skrining untuk kelompok-kelompok individu yang patut diduga dapat terinfeksi tuberkulosis paru. Di Jepang telah dilakukan penelitian yang mendapatkan hasil bahwa deteksi dini melalui investigasi pada pekerja kesehatan yang kontak dengan tuberkulosis paru atau untuk mengobati para penderita tuberkulosis laten diperlukan pemeriksaan IFN- $\gamma$ atau kuantifikasi dengan IGRA yang menggunakan QFTB-G. ${ }^{13}$ Penelitian di Portugis menyatakan bahwa sepanjang belum ditemukan pengetahuan tentang bagaimana perkembangan QFT + untuk individu secara pasti, harus dilakukan tes ulang sebelum diberikan pengobatan secara preventif. ${ }^{14}$

Pada keadaan kita tidak dapat memperoleh data penyebab (limited evidence), misalnya pasien extra pulmonary tuberkulosis, tuberkulosis paru dengan BTA negatif atau kultur negatif, serta tuberkulosis pada anak, IGRA dapat berkontribusi sebagai informasi tambahan. Hasil negatif IGRA tidak dapat diartikan tidak menderita tuberkulosis aktif. Dinyatakan bahwa IGRA tidak dapat menggantikan sebagai diagnostik standar seperti pemeriksaan mikrobiologi, tes klinis pemeriksaan radiologis untuk mendiagnosis tuberkulosis aktif. ${ }^{15}$ National Institute for Health and Clinical Excellence (NCE) menerbitkan suatu panduan yang menyatakan tata cara diagnosis dan deteksi dini untuk tuberkulosis, diantaranya adalah pada pekerja kesehatan apabila dilakukan tes Mantoux dan hasilnya negatif perlu dilakukan tes IFN-.${ }^{16}$ Minnesota Department Health menetapkan pemeriksaan darah untuk kegiatan preventif pada penanggulangan tuberkulosis yaitu dengan 3 kit: QFT-TB Gold, QFT- TB Gold in tube dan T. Spot-TB. ${ }^{17}$ Hal ini sesuai dengan telah ditemukan cut off point untuk pemeriksaan QFT-Tb Gold in tube sebesar $\geq 0,35 \mathrm{IU} / \mathrm{mL}$ dari 105 pasien ditemukan 10 pasien positif dengan TST $\geq 10 \mathrm{~mm}$, apabila diperiksa dengan QFT-TB Gold in tube dengan cut off point $\geq 0,35 \mathrm{IU} / \mathrm{mL}$ didapatkan 11 positif. ${ }^{18}$ Sedangkan pada penelitian ini diperoleh cut off point sebesar $\geq 3,277 \mathrm{pg} / \mathrm{mL}$ dan nilai sensitifitas dan spesifisitas $67,7 \%$. Ini hampir sama dengan sensitifitas pada tes Mantoux $(66,7 \%)$ dan QFT-G $(70,1 \%) .{ }^{19}$

Meskipun WHO telah menetapkan bahwa sensitifitas dan spesifisitas IGRA lebih tinggi dibanding TST, sehubungan dengan belum adanya gold standar, belum dapat ditentukan akurasi dari IFN- $\gamma$ pada spesifik populasi, termasuk pada penderita dengan HIV atau pasien immunocompromised, anak-anak, extra pulmonary tuberkulosis, serta kasus multi drug resistant. Juga belum pernah dihitung cost benefit dari pengukuran IFN- $\gamma$. Masih diperlukan penelitian lebih lanjut pada negara-negara dengan prevalensi tuberkulosis yang tinggi, negaranegara dengan minimnya dana, sarana serta prasarana. IGRA dianjurkan dilakukan di laboratorium klinik rutin bukan di laboratorium khusus tuberkulosis. ${ }^{18}$

Dengan melihat masalah-masalah tersebut, pemerik- 
saan IFN- $\gamma$ sebagai sarana deteksi dini disarankan untuk dilakukan sebagai proyek percontohan pada suatu daerah terlebih dahulu. Keuntungan memakai kit ini, jauh lebih murah dibandingkan kit-kit yang disarankan.

\section{Kesimpulan}

Penelitian ini menemukan perbedaan bermakna rerata kadar IFN- $\gamma$ antara kelompok kontak dengan kelompok tidak kontak serumah dengan penderita tuberkulosis paru (nilai $\mathrm{p}=0,004$ ). Rerata kadar IFN- $\gamma$ pada kontak serumah setelah dua tahun mengalami penurunan pada sebagian besar kasus (75\%). Sedangkan 25\% menunjukkan gejala klinis suspek tuberkulosis paru. Didapatkan hasil pemeriksaan mikrobiologis (BTA) menunjukkan 100\% negatif (pada kelompok kontak dan tidak kontak serumah). Hasil analisis ROC kadar IFN- $\gamma$ terhadap status klinis, didapatkan nilai AUC sebesar 70,4 $\%(95 \%$ CI 40,8\% - 99,9\%). Secara statistik nilai 70,4\% tergolong cukup kuat dipergunakan sebagai diagnosa. Nilai cut off point IFN- $\gamma \geq 3,277 \mathrm{pg} / \mathrm{mL}$ pada orang yang kontak serumah dengan penderita tuberkulosis paru dapat dinyatakan suspek tuberkulosis. Hasil sensitivitas dan spesifisitas yang diperoleh masing-masing sebesar $67,7 \%$.

\section{Saran}

Pemeriksaan kadar IFN- $\gamma$ dapat digunakan dalam kegiatan skrining untuk mendeteksi secara dini penularan pada kontak serumah dengan penderita tuberkulosis paru. Diusulkan Kementerian Kesehatan Republik Indonesia dapat melaksanakan sebagai proyek percontohan di suatu daerah dengan prevalensi tuberkulosis paru yang tinggi.

\section{Ucapan Terima Kasih}

Terima kasih kepada semua pihak yang telah membantu hingga dapat selesainya penelitian ini. Terutama kepada Direktorat Pendidikan Tinggi Kementerian Pendidikan dan Kebudayaan Republik Indonesia yang telah mendukung pendanaan penelitian ini, kemudian Kepala BKPM Semarang dan Kepala Laboratorium Gizi FK Universitas Diponegoro Semarang yang telah mengijinkan penelitian dilakukan. Juga kepada staf Laboratorium BKPM, dan staf Laboratorium Gizi Fakultas Kedokteran Universitas Diponegoro Semarang.

\section{Daftar Pustaka}

1. Atika DN. Pattern of community role development as an effort to increase tuberculosis patients coverage with passive case finding. Journal of Folia Medica Indonesiana. 2009; 45 (2): 108-11.

2. Departemen Kesehatan Republik Indonesia. Pedoman nasional pengendalian tuberkulosis. Jakarta: Departemen Kesehatan Republik Indonesia; 2009.
3. Indreswari SA, Suharyo. Kadar interferon-gamma pada kontak serumah dengan penderita tuberkulosis. Jurnal Kesehatan Masyarakat Nasional (Kesmas). 2012; 6 (5): 212-8.

4. World Health Organization. WHO Report 2011 Global Tuberculosis Control. Geneva: WHO; 2011 [cited 2013 August 10]. Available from: http://www.who.int/Tb/data.

5. Departemen Kesehatan Republik Indonesia. Situasi epidemiologi tuberkulosis Indonesia 2010. 2010 [diakses tanggal 10 Agustus 2013. Diunduh dalam: www.Tbindonesia.id.

6. Dinas Kesehatan Provinsi Jawa Tengah. Buku profil kesehatan Provinsi Jawa Tengah tahun 2012. Semarang: Dinas Kesehatan Provinsi Jawa Tengah; 2012.

7. Lee JY, Choi HJ, Park IN, Hong SB, Obr YM, Lim, et al. Comparison of two commercial interferon gamma assay for diagnosis Mycobacterium tuberculosis infection. European Respiratory Journal. 2006; 28 (1): 24-30.

8. Oksal D, Unsal E, Poyraraz B, Kaya A, Savas H, Sipit T, Gonullu U. The Value of serum interferon-gamma level in the differensial diagnosis of active and inactive pulmonary tuberculosis. Tuberkulosis Toraks. 2006; 54 (1): 17-21.

9. Oysal A, Torun T, Efe S, Gencer H, Tahaoqlu K, Bakir M. Evaluation of cut off values of Interferon gamma based assays in the diagnosis of $\mathrm{m}$. tuberculosis infect. The International Journal of Tuberculosis and Lung Disease. 2008; 12 (1): 50-6.

10. Quantikine Human IFN- $\gamma$ Immunoassay. For the quantitative determinations in cell culture supernates, serum, and plasma [manuscript on internet]. Minneapoli: R\&D; Available from: www.framinghamheartstudy.org/.../mcp11_7s_protocol.pdf.

11. Indreswari SA. Produksi IL-4, IFN- $\gamma$ (gamma) pada penderita tuberkulosis paru yang mendapatkan pengobatan strategi DOTS. Jurnal Kesehatan "Visikes". 2008; 9 (1): 7-11.

12. Sidi DP. Riwayat kontak tuberkulosis sebagai faktor risiko hasil uji tuberkulin positif [online]. 2009 [diakses tanggal 28 Oktober 2013]. Diunduh dalam: http://st283875.sitekno.com/?pg=articles\&article $=2590$.

13. Costa JT, Silva R, Sa R, Cardoso MJ, Nienhaus A. Serial testing with interferon gamma release assay in Portuguse health workers. International Archives of Occupational Environmental Health. 2011 Apr; 84 (4): 4619.

14. European Centre for Disease Prevention and Control. Use interferon gamma release assay in support of TB diagnosis. Stockholm: ECDC; 2011.

15. National Institute for Health and Clinical Excellence. Tuberculosis clinical diagnosis and management of tuberculosis, and measures for its prevention and control. NICE clinical guideline 117. March 2011 [cited 2013 Jul 30]. Available from: www.evidence.nhs.uk.

16. Minnesotta Department of Health TB Prevention and Control Program. Guidelines for TB blood testing. Minnesotta USA; 2011 [cited 2013 Oct 28]. Available from: www.health.state.mn.us/divs/.../Tb_/ igraguide.pdf.

17. Legesse M, Ameni G, Mamo G, Medhin G, Bjune G, Abebe F. Community-based cross-sectional survey of latent tuberculosis infection in Afar pastoralist Ethiopia using Quantiferon-TB Gold In-Tube and tuberculosis skin test. BMC Infectious Disease. 2011; 11 (89).

18. Parsons LM, Somoskovi A, Gutierrez C, Lee E, Paramasivan CN, Abinuku A, et al. Laboratory diagnosis of tuberculosis in resource-Poor 
Kesmas, Jurnal Kesehatan Masyarakat Nasional Vol. 9, No. 1, Agustus 2014

countries: challenges and opportunities. Clinical Microbiology Reviews. 2011 April; 24 (2): 314-50.

19. Dogra S, Narang N, Mandiratta DK, Chaturvedi P, Reingold AL, Colford Jr JM, et al. Comparison of whole blood interferon gamma as- say with tuberculin skin testing for the detection of tuberculosis infection in hospitalized children in rural India. Journal of Infection. 2007; 54: 267-76. 